\section{Peripatetic naturalist}

Linnaeus's Öland and Gotland Journey 1741. Translated from the Swedish edition of 1745 by Marie Åsberg and William T. Stearn. Pp. viii +220 . (Academic: London; Linnean Society of London, February 1974.) £6; \$17.50.

IN 1741, at the age of thirty-four, Carl Linnaeus was already an eminent naturalist and professor of medicine when he set out to survey the natural resources of the Baltic islands of Öland and Gotland. Taking with him six male companions, he travelled at the behest of the Swedish Parliament, which was intent on economic recovery through the exploitation of domestic raw materials. While familiarising himself with the natural history of the islands, Linnaeus was instructed particularly to look for plants suitable for making dyes, or with pharmacognostic value, and for clay or earth suitable for the production of such things as pottery and pipes. He was also required to keep an accurate diary, which was pubished in 1745 and is now made accessible to English speaking readers by Drs Åsberg and Stearn in their enjoyable translation. The style is that of daily field notes that have been tidied up grammatically, but not turned into a continuous narrative. Although not competing as bedtime reading with the picaresque novels of the period, the diary provides some interesting insights into the observational methods and common sense attitudes of the man who is remembered chiefly for giving the world the binomial system of nomenclature for plants and animals.

The members of the expedition left Stockholm on May 15, and, travelling on horseback, reached the coastal town of Kalmar on May 27. After waiting in vain for the weather to improve, they embarked on the ferry for the threemile passage to Öland, hastened by two cases of spotted fever in the house where they had stayed. By July 27, when they returned to the mainland, they had traversed much of this narrow island, as well as Gotland, on which they spent thirty-four days. On the latter, the diary disdainfully records, there were no persons of standing except for two judges and a captain.

Linnaeus was well pleased with the journey. He recorded a hundred plants then unknown in Sweden, including several with pharmaceutical uses, such as Ruta muraria (now known as Asplenium ruta-muraria) which previously had been imported.

Finding woad (Isatis) growing in abundance on Klasen, a small island near Gotland, he recommended that it would be worthwhile to sow the species more extensively. In other places the extraction of dye from plants was recorded assiduously for the parliament.
Usually leaves or roots were boiled together with yarn, which was subsequently treated with an alkaline concoction to fasten the colour.

By such a procedure, yellow dye was obtained from burmarigold (Bidens tripartita) and juniper moss (Cetraria juniperina), brownish red from Origanum vulgare, a lemon colour from apple bark and dark brown from soot. But no use had been found for the red colour of the rotting seaweed that covered some of the shores of Öland, and "gave off such a stench, as if ten horses had been roasted in the sun". Seaweed, however, was put to good use in other places, as manure and for thatching roofs.

Local remedies were found for all manner of ills. These included the moss Sphagnum palustre which was cooked in beer and laid on swollen legs; grasshoppers that spat out a black liquid, causing warts to disappear; the root of Valeriana officinalis which was used for hysteria (Linnaeus failed to record how), and Solanum officinarum, ground up with spiders web and rancid pork to treat whitlows.

While the expedition was at Forosünd on Gotland the farmers left their fields and fences to indulge in feasting and dancing. Here Linnaeus drew a picture of a seamless bagpipe made from a seal's stomach, with the modulator placed in the pylorus and the base inserted into the oesophagus. Seals (Phoca vitulina) served other purposes in the economy of Gotland and there are several accounts of hunting methods. The beasts were caught in nets and either harpooned or bludgeoned on their very sensitive noses. Seal lard was sold, the meat was eaten, and the fresh fat could be used instead of butter for frying pancakes. Porpoises were sometimes caught in the nets accidentally, and Linnaeus thought it quite remarkable that nobody had developed the art of trapping them, for their lard was as useful as that from seals.

Interspersed among meticulous accounts of this sort, and descriptions of fences, corn fields, runic stones, flora and fauna, Linnaeus provided notes on local superstitions. This he did "more to entertain my reader than for any other reason". On mainland Sweden the rational professor was not imnressed by the belief that when a farmer's cow died he could transfer the bad luck to his neighbour's cattle by burying the carcase in the neighbour's field or dung hill. Such beliefs "and infinitely much more of similar rubbish" were dismissed as relics of heathen and popish times. Linnaeus' prescription for the eradication of such things was to instruct future theologians well in natural history and natural philosophy, since nothing served so well to check superstitions as the contempt of the clergy. He resolved to teach his students at Uppsala University everything necessary for them to go into the countryside and instruct their parishioners to best advantage. This he did, and much more besides, as botanists know. Now this diary shows them an aspect of Linnaeus with which they may not have been familiar.

Mary Lindley

\section{Scientists in the world}

Towards a Political Sociology of Science. By Stuart S. Blume. Pp. xiit 288. (Free Press: New York; CollierMacmillan: London, April 1974.) £4.95.

LIKE all really good empirical studies in the human sciences, this one is addressed to a theoretical problem. That is, the nature of the scientific community. The author argues that, for sociological analysis, it must be considered as both involved in national political life and also internally differentiated by power relations between élites and others.

In the post-Rothschild epoch of fully industrialised science this thesis is hardly likely to cause outrage among working scientists. But it does represent an important development in the sociology of science. Lest natural scientists dismiss it on that ground they should recall how naive and shortsighted were the dominant assumptions of scientists' own common sense about the social activity of science all through the postwar period.

In the sociology of science, debate is still organised around the ideas of Robert K. Merton. We can distinguish three phases of 'Mertonism', a set of received research paradigms much simpler than the contemporary enquiries by Merton himself. At the beginning was the attempt, through the 'four norms' and the 'ethos' of science, to identify the implicit value system of scholarship with that of the most enlightened democracy, political and economic. In the post-war period Mertonism shifted to the motivational machinery by which men in this idealised scientific community are induced to merge self interest with the common good. Recently, more realistic details have been introduced, exhibiting the community as a geronto-aristocracy, and seeing how well this social structure works.

Even this 'late Mertonism' imagines a community of 'pure' science, doing its own praiseworthy thing in a social vacuum. Blume contends that such a model is drastically over-simple. His main thesis is that the élites in science are maintained in power partly by their external connections and that they 